\author{
Ю. М. Степась, Л. Є. Лаповець, В. М. Акімова, 3. Я. Лавро \\ ЛЬВІВСЬКИЙ НАЦІОНАЛЬНИЙ МЕДИЧНИЙ УНІВЕРСИТЕТ ІМЕНІ ДАНИЛА ГАЛИЦЬКОГО
}

\title{
ОСОБЛИВОСТІ ЗМІН ПОКАЗНИКІВ СИСТЕМИ ГЕМОСТАЗУ ТА РІВНЯ С-РЕАКТИВНОГО ПРОТЕЇНУ У ХВОРИХ НА ГОСТРИЙ ХОЛЕЦИСТИТ
}

Вступ. Гострий холецистит, частим ускладненням якого є механічна обструкція жовчних проток, характеризується спектром симптомів - від місцевого запального процесу до суттєвих змін у гепатоцитах та холестатичної інтоксикації. Ці симптоми часто проявляються порушенням усіх орункцій печінки, що бере участь у синтезі більшості білків, як системи гемостазу, так і білків гострої фрази.

Мета дослідження - провести порівняльний аналіз показників системи гемостазу та рівня С-реактивного протеїну (СРП) у хворих на гострий калькульозний холецистит (ГКХ).

Методи дослідження. Обстежено 67 осіб: 20 практично здорових, 25 хворих на ГКХ без ускладнень (1-ша група) та 22 пацієнтів з ГКХ, ускладненим обтураційною жовтяницею (2-га група). Систему гемостазу було досліджено шляхом визначення кількості тромбоцитів, протромбінового часу (Пч), активованого парціального тромбопластинового часу (АПТЧ), концентрації фрібриногену, вмісту розчинних фрібринмономерних комплексів (РФМК), активності антитромбіну III (АТIII) та Хагеман-залежного фрібринолізу. А також визначали рівень СРП у сироватці крові.

Результати й обговорення. Встановлено вірогідне подовження ПЧ, АПТЧ, підвищення концентраціі фрібриногену, вмісту РФМК, Хагеман-залежного фрібринолізу та рівня СРП у групах хворих на ГКХ порівняно з контрольною ( $p<0,05, p<0,001)$. Крім того, виявлено вірогідне зниження рівня АTIII та зменшення кількості тромбоцитів у пацієнтів з ГКХ порівняно з показниками у практично здорових осіб $(p<0,05)$.

Висновки. В основі змін показників системи гемостазу, найімовірніше, лежить гепатоцелюлярна недостатність як причина зниження синтезу багатьох компонентів гемостазу на фоні запального ураження в печінці. Порушення первинного і вторинного гемостазу при недостатній антикоагулянтній активності можуть призвести до поліорганних уражень гемодинаміки та мікроциркуляції. Збільшення вмісту РФМК у плазмі крові дає змогу передбачити наявність синдрому ДВЗ, а подовження АПТЧ та ПЧ буде характеризувати цей синдром як використання фракторів згортання у фазу гіпокоагуляції. Вірогідне підвищення рівня СРП у хворих на ГКХ, ускладнений обтураційною жовтяницею, вказує на його участь у прогресуванні запального процесу.

КЛЮЧОВІ СЛОВА: гострий холецистит; обтураційна жовтяниця; система гемостазу; синдром дисемінованого внутрішньосудинного згортання; С-реактивний протеїн.

ВСТУП. Гострий холецистит є одним з найпоширеніших захворювань у структурі гострої хірургічної патології органів черевної порожнини. Частота захворюваності на дану патологію неухильно зростає і збільшується за кожне десятиріччя у два рази. Відомо, що найчастіше причиною гострого холециститу $є$ жовчнокам'яна хвороба, яка може супроводжуватися обтураційною жовтяницею (ОЖ) [1].

Гострий холестаз при механічній обструкції жовчних проток характеризується спектром симптомів - від місцевого запального процесу до суттєвих змін у гепатоцитах та холестатичної інтоксикації. Ці симптоми часто проявляються

(с Ю. М. Степась, Л. Є. Лаповець, В. М. Акімова, 3. Я. Лавpo, 2017. порушенням усіх срункцій печінки, що бере участь у синтезі більшості білків, як системи гемостазу, так і білків гострої фрази $[1,2]$.

Доведено, що С-реактивний протеїн (СРП) це мультифрункціональний білок гострої фази, що синтезується в печінці та відіграє важливу роль при запаленні [3]. Особливість його в тому, що він не специфрічний (стосовно першопричини запалення), проте виявляє високу кореляцію концентрації в крові 3 тяжкістю хвороби $[7,8]$. Відомо, що шляхи запалення і коагуляції тісно пов'язані між собою. А найбільш яскравим проявом порушення гемостазу та гемореології під впливом запального процесу може бути розвиток однієї з фрорм синдрому дисемінованого внутрішньосудинного згортання (ДВ3) $[8,9]$. 
Мета дослідження - провести порівняльний аналіз показників системи гемостазу та рівня СРП у хворих на гострий калькульозний холецистит (ГКX).

МЕТОДИ ДОСЛІДЖЕННЯ. Було обстежено 47 хворих на ГКХ, з них 36 жінок (76,6 \%) та 11 чоловіків $(23,4 \%)$. Середній вік пацієнтів становив $(52,82 \pm 2,21)$ року. До 1-ї групи ввійшли 25 $(53,2 \%)$ хворих на ГКХ без ускладнень, до 2-ї $22(46,8 \%)$ пацієнти 3 ГКХ, ускладненим ОЖ. Контрольну групу становили 20 практично здорових осіб (ПЗО) відповідних з пацієнтами дослідних груп віку і статі. Діагноз ГКХ було встановлено на підставі клінічних, лабораторно-біохімічних та інструментальних методів.

Систему гемостазу було досліджено шляхом визначення таких показників, як кількість тромбоцитів, протромбіновий час (ПЧ), активований парціальний тромбопластиновий час (АПТЧ), концентрація фрібриногену, вміст розчинних фрібрин-мономерних комплексів (РФМК), активність антитромбіну III (АТIII) та Хагеман-залежного фрібринолізу. ПЧ та АПТЧ визначали за стандартними коагулогічними методиками, а РФМК - за допомогою паракоагуляційного ортофенантролінового тесту. При цьому використовували реактиви фрірми "ТЕХНОЛОГІЯ-СТАНДАРТ" (м. Барнаул, Росія). Активність Хагеманзалежного фрібринолізу визначали за швидкістю лізису еуглобулінового згустку плазми крові із застосуванням набору реактивів фрірми "SIMKO LTD" (м. Львів). Концентрацію фрібриногену в плазмі крові визначали за методикою Р. А. Рутберг. Активність ATIII визначали шляхом інкубування розведеної цитратної плазми зі стандартною кількістю тромбіну, а потім за часом згортання фрібриногену визначали антитромбінову активність. При цьому використовували набір реактивів фрірми "SIMKO LTD" (м. Львів) $[4,5]$.

Дослідження щодо визначення рівня СРП у сироватці крові проводили імунотурбідиметричним методом за допомогою автоматичного біохі- мічного аналізатора COBAS INTEGRA 400 PLUS ("ROCHE DIAGNOSTICS GmbH", Німеччина).

Взяття крові проводили відразу при госпіталізації хворих у відділення шляхом забору з ліктьової вени за допомогою системи Vacutainer.

Для статистичної обробки матеріалу використовували пакет прикладних програм STATISTICA 6.0. Результати наведено як $\mathrm{M} \pm \mathrm{m}$, де $\mathrm{M}$ середнє значення показника, $\mathrm{m}$ - стандартна похибка. Вірогідність отриманих результатів оцінювали за t-критерієм Стьюдента. Зміни вважали вірогідними при р<0,05 [6].

РЕЗУЛЬТАТИ Й ОБГОВОРЕННЯ. ПОРіВняльний аналіз показників системи гемостазу та рівня СРП у хворих на ГКХ виявив значні, статистично вірогідні відмінності (рис., табл.).

Два незалежних шляхи активації процесів згортання, внутрішній і зовнішній, оцінювали шляхом визначення АПТЧ та ПЧ відповідно. Встановлено, що у хворих на ГКХ без ускладнень значення ПЧ вірогідно зростало в 1,27 раза порівняно з показником у ПЗО $(p<0,05)$. У 2 -й групі пацієнтів, порівняно з контрольною, даний показник був вірогідно вищим в 1,33 раза, а порівняно 3 1-ю - практично не відрізнявся від такого (р>0,05). Щодо АПТЧ, то в 1-й групі хворих він вірогідно перевищував показник контрольної групи в 1,2 раза $(p<0,05)$, проте не виходив за

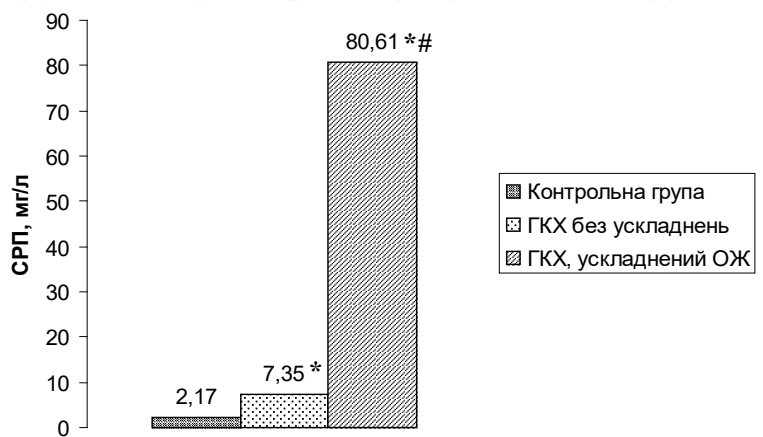

Рис. Рівень С-реактивного протеїну у хворих на ГКХ (* - вірогідність відмінності порівняно з показниками контрольної групи (р<0,001, p<0,05); \# - вірогідність відмінності порівняно з показниками 1-ї групи $(p<0,001))$.

Таблиця - Порівняльний аналіз показників системи гемостазу у хворих

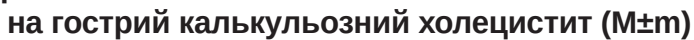

\begin{tabular}{|c|c|c|c|}
\hline \multirow{2}{*}{ Показник } & \multirow{2}{*}{$\begin{array}{c}\text { Контрольна група } \\
(n=20)\end{array}$} & \multicolumn{2}{|c|}{ Група хворих } \\
\hline & & 1-ша $(n=25)$ & 2-га $(n=22)$ \\
\hline Тромбоцити, ×10\%/л & $282 \pm 12,05$ & $207,58 \pm 5,89 *$ & $168,55 \pm 4,97^{\text {*\# }}$ \\
\hline ПЧ, c & $13,64 \pm 0,23$ & $17,31 \pm 0,73^{*}$ & $18,2 \pm 1,6^{*}$ \\
\hline АПТЧ, с & $31,57 \pm 1,13$ & $37,74 \pm 1,39 *$ & $50,85 \pm 1,86^{\star \#}$ \\
\hline Фібриноген, г/л & $3,22 \pm 0,12$ & $4,6 \pm 0,33^{*}$ & $9,2 \pm 0,61^{\text {*\# }}$ \\
\hline РФМК, МГ\%/100 мЛ & $3,41 \pm 0,09$ & $6,75 \pm 0,64^{*}$ & $15,72 \pm 1,46^{\star \#}$ \\
\hline Хагеман-залежний фрібриноліз, хв & $16,24 \pm 0,89$ & $18,94 \pm 0,7$ & $29,73 \pm 2,04^{\star \#}$ \\
\hline ATIII, \% & $100,81 \pm 1,81$ & $85,08 \pm 1,92^{*}$ & $70,64 \pm 1,91^{\text {*\# }}$ \\
\hline
\end{tabular}

Примітки:

1. * - вірогідність відмінності порівняно з показниками контрольної групи $(p<0,05)$.

2. \# - вірогідність відмінності порівняно з показниками 1-ї групи (p<0,05). 
межі норми. У пацієнтів з ГКХ, ускладненим ОЖ, відзначали подовження АПТЧ в 1,61 раза $(p<0,05)$ порівняно зі значенням контрольної групи та в 1,35 раза $(p<0,05)$ відповідно до значення даного показника у хворих на ГКХ без ускладнень. Отримані результати свідчать про схильність хворих на ГКХ до гіпокоагуляції, причиною якої може бути недостатність як факторів протромбінового комплексу (VII, X, V, II), так і фракторів внутрішнього шляху згортання (VIII, XI, IX). Такий стан може бути спровокований порушенням синтезу вказаних фракторів згортання у клітинах печінки, при ураженні якої їх кількість, відповідно, зменшується, та нестачею вітаміну $\mathrm{K}[5,9,11]$.

Дослідження концентрації фрібриногену в крові хворих на ГКХ показали її вірогідне збільшення. Так, у 1-й групі пацієнтів рівень фрібриногену був у 1,43 раза вищим порівняно 3 показником контрольної групи $(p<0,05)$. У хворих на ГКХ, ускладнений ОЖ, його концентрація вірогідно перевищувала значення групи ПЗО у 2,86 раза $(\mathrm{p}<0,05)$, а значення групи хворих на ГКХ без ускладнень - у 2 рази відповідно $(p<0,05)$. Таке зростання концентрації фрібриногену характерне для гострої фрази запалення, оскільки фрібриноген розглядають як один із гострофразних показників запалення і, як правило, він має транзиторний характер. А це, у свою чергу, сприяє збільшенню густини крові та порушує їі реологію [8, 9].

При оцінці кількості РФМК, що відображають наявність внутрішньосудинного тромбоутворення, відзначено вірогідне їх збільшення у 1-й та 2-й дослідних групах, порівняно з контрольною, в 1,43 і 4,61 раза відповідно $(p<0,05)$. Рівень РФМК у хворих 2-ї групи перевищував значення 1 -ї групи у 2,33 раза $(p<0,05)$. Виявлення РФМК у крові прямо вказує на наявність патологічно активного фрібрину та існування синдрому ДВЗ у хронічній формі $[5,10]$.

Характер змін фрібринолізу оцінювали за визначенням Хагеман-залежного фрібринолізу. Так, у 2-й групі хворих на ГХК було відмічено вірогідне зростання даного показника в 1,83 раза $(p<0,05)$ порівняно 3 контрольною групою та в 1,57 раза $(p<0,05)$ - порівняно з 1-ю. Такі результати вказують на зниження фрібринолітичного потенціалу крові $[4,5]$.

Для оцінки стану антикоагулянтної активності досліджували рівень АТІІІ - основного потужного інгібітора фрібрину, на частку якого припадає близько 75 \% усієї антикоагулянтної активності плазми, та активації практично всіх фракторів згортання крові, перш за все фрактора Хагемана. При запальних пошкодженнях ATIII споживається та інактивується шляхом протеолізу $[5,9,11]$. Так, у хворих на ГКХ без ускладнень зміни рівня
ATIII супроводжувалися вірогідним зниженням на 15,6 \% $(p<0,05)$ порівняно 3 контрольною групою. Зміна концентрації АTIII у пацієнтів 3 ГКХ, ускладненим ОЖ, була вірогідно нижчою на 29,9\% $(p<0,05)$ порівняно 3 контрольною групою і на 17 \% $(p<0,05)$ - порівняно 3 1-ю. Такі показники концентрації АTIII $€$, можливо, одним із множинних механізмів фрормування структурних змін системних проявів захворювання внаслідок підвищеного його використання через великий запальний потенціал і можуть свідчити про фрормування хронічного синдрому ДВ3 [4, 9].

Крім того, виявлено вірогідне зменшення кількості тромбоцитів у хворих дослідних груп порівняно з контрольною. Так, у 1-й і 2-й групах хворих на ГКХ даний показник був на 26,4 \% $(p<0,05)$ та 40,2 \% (p<0,05) нижчим порівняно 3 контрольною групою. У 2-й групі пацієнтів з ГКХ кількість тромбоцитів була вірогідно на 18,8 \% меншою від показника 1-ї групи хворих $(p<0,05)$.

Відомо, що одним із маркерів гострої фрази запалення є СРП, синтез якого посилюється вже через 6-8 год після початку запального процесу, сягаючи максимуму через 1-2 дні $[7,8]$. Наші дослідження показали такі показники рівня СРП у хворих на ГКХ (рис.). Так, у групі пацієнтів 3 ГКХ без ускладнень він становив $(7,35 \pm 1,45)$ мг/л і був вірогідно вищим у 3,4 раза $(p<0,001)$ порівняно з показником контрольної групи. У 2-й групі хворих рівень СРП складав $(80,61 \pm 8,21)$ мг/л і в 37,1 раза $(p<0,05)$ вірогідно перевищував показник контрольної групи та майже в 11 разів $(p<0,001)$ - показник групи пацієнтів з ГКХ, ускладненим ОЖ.

ВИСНОВКИ. 1. В основі змін показників системи гемостазу, що характеризуютьсяподовженням ПЧ, АПТЧ, зменшенням кількості тромбоцитів, зниженням фрібринолітичного та антикоагулянтного потенціалу крові, найімовірніше, лежить гепатоцелюлярна недостатність як причина зниження синтезу багатьох компонентів гемостазу на ороні запального ураження в печінці.

2. Зниження активності АTIII свідчить про виснаження адаптаційних можливостей гемостазу. Порушення первинного і вторинного гемостазу при недостатній антикоагулянтній активності можуть призвести до поліорганних уражень гемодинаміки та мікроциркуляції.

3. Збільшення вмісту РФМК у плазмі крові дає змогу передбачити наявність синдрому ДВ3, а подовження АПТЧ та Пч буде характеризувати цей синдром як використання фракторів згортання у фразу гіпокоагуляції.

4. Вірогідне підвищення рівня СРП у хворих на ГКХ, ускладнений ОЖ, вказує на його участь у прогресуванні запального процесу. 
СПИСОК ЛІТЕРАТУРИ

1. Іваночко Н. Я. Сучасні аспекти перебігу та лікування гострого калькульозного холециститу в осіб похилого та старечого віку / Н. Я. Іваночко, М. Г. Гончар, Я. М. Кучірка // Шпитальна хірургія. - 2009. № 1. - С. 65-67.

2. Гонський Я. І. Біохімія людини : підручник / Я. І. Гонський, Т. П. Максимчук, М. І. Калинський. -2-ге вид. - Тернопіль : Укрмедкнига, 2002. - 744 с.

3. Клінічна біохімія : підручник / за заг. ред. Г. Г. Луньової. - К. : Атіка, 2013. - 1156 с.

4. Баркаган 3. С. Диагностика и контролируемая терапия нарушений гемостаза / 3. С. Баркаган, А. П. Момот. - М. : Ньюдиамед, 2001. - 296 с.

5. Момот А. П. Патология гемостаза. Принципы и алгоритмы клинико-лабораторной диагностики / А. П. Момот. - СПб. : Форма Т, 2006. - 208 с.

6. Боровиков В. STATISTICA: искусство анализа данных на компьютере. Для профессионалов / В. Боровиков. - СПб. : Питер, 2001. - 656 с.
7. Вельков В. В. Прокальцитонин и С-реактивный белок в современной лабораторной диагностике / В. В. Вельков // Лаб. диагностика. - 2010. - № 4. C. $39-76$.

8. Гусев Д. Е. Роль С-реактивного белка и других маркеров острой фразы воспаления / Д. Е. Гусев, Е. Г. Пономарь // Клинич. медицина. - 2006. - № 2. C. 25-30.

9. New fundamentals in hemostasis / H. H. Varsteeg, J. W. M. Heemskerk, M. Levi [et al.] // Physiol. Rev. 2013. - 93. - P. 327-358 .

10. Horan J. T. Fibrin degradation products, fibrin monomer and soluble fibrin in disseminated intravascular coagulation / J. T. Horan, C. W. Francis // Semin. Thromb. Hemost. - 2004. - 21. - P. 657-667

11. Hemostasis and thrombosis in patients with liver disease: The ups and downs / T. Lisman, S. H. Caldwell, A. K. Burroughs [et al.] // J. Hepatology. - 2010. - 53 (2). - P. 362-371.

\section{REFERENCES}

1. Ivanochko, N.Ya., Honchar, M.H., \& Kuchirka, Ya.M. (2009). Suchasni aspekty perebihu ta likuvannia hostroho kalkuloznoho kholetsystytu $v$ osib pokhyloho ta starechoho viku [Modern aspects of the course and treatment of acute calculous cholecystitis in elderly and senile age]. Shpytalna khirurhiia - Hospital Surgery, 1, 65-67 [in Ukrainian].

2. Honskyi, Ya.I., Maksymchuk, T.P., \& Kalynskyi, M.I. (2002). Biokhimiia liudyny [Human biochemistry]. Ternopil: Ukrmedknyha [in Ukrainian].

3. Lunova, H.H. (eds.). (2013). Klinichna biokhimiia [Clinical biochemistry]. Kyiv: Atika [in Ukrainian].

4. Barkagan, Z.S., \& Momot, A.P. (2001). Diagnostika i kontroliruemaya terapiya narusheniy gemostaza [Diagnosis and controlled therapy of hemostasis disorders]. Moscow: Nyudiamed [in Russian].

5. Momot, A.P. (2006). Patologiya gemostaza. Printsipi i algoritmy kliniko-laboratornoyi diagnostiki [Pathology of hemostasis. Principles and algorithms of clinical and laboratory diagnostics]. St. Petersburg: Forma T [in Russian].

6. Borovikov, V. (2001). STATISTICA: iskusstvo analiza dannyh na kompyutere. Dlya professionalov
[STATISTICA: the art of data analysis on a computer. For professionals]. St. Petersburg: Piter [in Russian].

7. Velkov, V.V. (2010). Prokaltsitonin i S-reaktivnyi belok $v$ sovremennoy laboratornoy diagnostike [Procalcitonin and C-reactive protein in modern laboratory diagnostics]. Labor. Diagnostika - Laboratory diagnostics, 4 , 39-76 [in Russian].

8. Gusev, D.E., \& Ponomar, E.G. (2006). Rol Sreaktivnogo belka i drugih markerov ostroyi fazy vospaleniya [The role of $\mathrm{C}$-reactive protein and other markers of the acute phase of inflammation]. Klin. MeditsinaClinical Medicine, 2, 25-30 [in Russian].

9. Varsteeg, H.H., Heemskerk, J.W.M., \& Levi, M. (2013). New fundamentals in hemostasis. Physiol. Rev., 93, 327-358.

10. Horan, J.T., \& Francis, C.W. (2004). Fibrin degradation products, fibrin monomer and soluble fibrin in disseminated intravascular coagulation. J. Hepatology, 21, 657-667.

11. Lisman, T., Caldwell, S.H., \& Burroughs, A.K. (2010). Hemostasis and thrombosis in patients with liver disease: The ups and downs. J. Hepatology, 53 (2), 362371.

Ю. М. Степась, Л. Е. Лаповец, В. М. Акимова, 3. Я. Лавро ЛЬВОВСКИЙ НАЦИОНАЛЬНЫЙ МЕДИЦИНСКИЙ УНИВЕРСИТЕТ ИМЕНИ ДАНИЛА ГАЛИЦКОГО

\section{ОСОБЕННОСТИ ИЗМЕНЕНИЙ ПОКАЗАТЕЛЕЙ СИСТЕМЫ ГЕМОСТАЗА И УРОВНЯ С-РЕАКТИВНОГО ПРОТЕИНА У БОЛЬНЫХ ОСТРЫМ ХОЛЕЦИСТИТОМ}

\section{Резюме}

Вступление. Острый холецистит, частым осложнением которого является механическая обструкция желчных протоков, характеризуется спектром симптомов - от местного воспалительного процесса к существенным изменениям в гепатоцитах и холестатической интоксикации. Эти симптомы часто проявляются нарушением всех фрункций печени, которая принимает участие в синтезе большинства белков, как системы гемостаза, так и белков острой фразы. 
Цель исследования - провести сравнительный анализ показателей системы гемостаза и уровня С-реактивного протеина (СРП) у больных острым калькулезным холециститом (ОКХ).

Методы исследования. Обследовано 67 человек: 20 практически здоровыХ, 25 больных ОКХ без осложнений (1-я группа) и 22 пациента с ОКХ, осложненным обтурационной желтухой (2-я группа). Cuстему гемостаза было исследовано путем определения количества тромбоцитов, протромбинового времени (ПВ), активированного парциального тромбопластинового времени (АПТВ), концентрации фрибриногена, содержания растворимых фрибрин-мономерных комплексов (РФМК), активности антитромбина III (ATIII) и Хагеман-зависимого фьибринолиза. А также определяли уровень СРП в сыворотке крови.

Результаты и обсуждение. Установлено достоверное удлинение ПВ, АПТВ, повышение концентрации фибриногена, содержания РФМК, Хагеман-зависимого фрибринолиза и уровня СРП в группах больных ОКХ по сравнению с контрольной (p<0,05, p<0,001). Кроме того, выявлено достоверное снижение уровня ATIII и уменьшение количества тромбоцитов у пациентов с ОКХ по сравнению с показателями у практически здоровых лиц ( $p<0,05)$.

Выводы. В основе изменений показателей системы гемостаза, скорее всего, лежит гепатоцеллюлярная недостаточность как причина снижения синтеза многих компонентов гемостаза на фоне воспалительного поражения в печени. Нарушения первичного и вторичного гемостаза при недостаточной антикоагулянтной активности могут привести к полиорганным поражениям гемодинамики и микроциркуляции. Увеличение содержания РФМК в плазме крови позволяет предположить наличие синдрома ДВС, а удлинение АПТВ и ПВ будет характеризовать этот синдром как использование фракторов свертывания в фразу гипокоагуляции. Достоверное повышение уровня СРП у больных ОКХ, осложненным обтурационной желтухой, указывает на его участие в прогрессировании воспалительного процесса.

КЛЮЧЕВЫЕ СЛОВА: острый холецистит; обтурационная желтуха; система гемостаза; синдром диссеминированного внутрисосудистого свертывания; С-реактивный протеин.

J. M. Stepas, L. E. Lapovets, V. M. Akimova, Z. Ya. Lavro DANYLO HALYTSKYI LVIV NATIONAL MEDICAL UNIVERSITY

\section{PECULIARITIES OF HEMOSTATIC PARAMETERS AND C-REACTIVE PROTEIN CHANGES IN PATIENTS WITH ACUTE CHOLECYSTITIS}

\section{Summary}

Introduction. Acute cholecystitis, which is frequently complicated by the bile ducts mechanical obstruction, is characterized by a variety of symptoms - from local inflammation to significant changes in hepatocytes and cholestatic intoxication. These symptoms often manifest violation of the liver functions, which is involved in the synthesis of most proteins, as the system of hemostasis, as well as the so-called «acute phase proteins».

The aim of the study - to determine and conduct comparative analysis of hemostatic parameters and level of $C$-reactive protein (CRP) in patients with acute calculous cholecystitis (ACC).

Methods of the research. 67 people were examined: 20 of them - healthy, 25 - patients with ACC without complications (1 group) and 22 - patients with ACC complicated with obstructive jaundice (2 group ). The study of hemostasis was performed by determining platelet count, prothrombin time (PT), activated partial thromboplastin time (APTT), fibrinogen concentration, the content of soluble fibrin-monomeric complexes (SFMC), antithrombin III activity (ATIII) and Hagemann-dependent fibrinolysis. Determination of CRP level in blood serum was also performed.

Results and Discussion. We found a significant elongation of the PT, APTT, increased concentration of fibrinogen, SFMC content, Hagemann-dependent fibrinolysis and the level of CRP in patients with ACC in comparison with the control group $(p<0.05, p<0.001)$. In addition, a significant decrease in ATIII level and reduction of the number of platelets in patients with ACC in comparison with the practically healthy people $(p<0.05)$ was found.

Conclusions. The basis of the identified changes in parameters of hemostasis system most likely lies in hepatocellular insufficiency as the cause of the reduced synthesis of many components of haemostasis on the background of inflammatory liver damage. Disorders of primary and secondary hemostasis with insufficient anticoagulants activity can lead to multiple lesions in hemodynamics and microcirculation. The increase in the content of SFMC in plasma suggests the presence of DIC syndrome. A prolongation of PT and APTT will characterize DIC syndrome as the use factors of a phase hypocoagulation.A significant increase in the level of CRP in patients with ACC complicated with obstructive jaundice indicates its involvement in the progress of the inflammatory process.

KEY WORDS: acute cholecystitis; obstructive jaundice; hemostasis system; disseminated intravascular coagulation syndrome; C-reactive protein.

Отримано 20.02.17

Адреса для листування: Ю. М. Степась, Львівський національний медичний університет імені Данила Галицького, вул. Пекарська, 69, Львів, 79010, Україна, e-mail: stepas1983@i.ua. 